Jurnal Penelitian dan Pengabdian Kepada Masyarakat Bidang ilmu Pendidikan

\title{
Pengaruh Model Pembelajaran Kooperatif Tipe STAD Terhadap Hasil Belajar Siswa Sekolah Dasar
}

\author{
Asmedy \\ Program Studi Pendidikan Teknologi Informasi, STKIP Yapis Dompu \\ E-mail: asmedy.ntb@gmail.com
}

Article History: Received: 2021-01-05 || Revised: 2021-02-15 || Published: 2021-03-31

Sejarah Artikel : Diterima: 2021-01-05 || Direvisi: 2021-02-15 || Dipublikasi: 2021-03-31

\begin{abstract}
The research purpose is to determine the effect of the STAD cooperative learning model on student learning outcomes of SD Negeri 1 Dompu in the 2019/2020 learning year. This type of research is a quasi-experimental study with a quantitative approach. The population was all grade $V$ students totaling 94 students. The sample used was the VC class students, amounting to 31 people as the experimental class and 31 students in the VA class as the control class. The sampling technique was using purposive sample. Data obtained through the pretest and post-test then analyzed using the t-test. The final test data for the sample class were analyzed using the $t$-test. The t-test results obtained tcount $>$ table, 17.339>1.670. Obtained $t$ count is greater than the table at an error level of 5\% and dk of 5 . Based on the proposed hypothesis there is an effect of the STAD cooperative learning model on learning outcomes of Class V students of SD Negeri 1 Dompu in the 2019/2020 learning year
\end{abstract}

Keywords: Education, Cooperative, STAD

\begin{abstract}
Abstrak
Penelitian ini bertujuan untuk mengetahui pengaruh model pembelajaran kooperatif tipe STAD terhadap hasil belajar siswa SD Negeri 1 Dompu tahun pembelajaran 2019/2020. Jenis penelitian ini ialah kuasi eksperimen dengan pendekatan kuantitatif. Populasi ialah seluruh peserta didik kelas V yang berjumlah 94 peserta didik. Sampel yang digunakan adalah peserta didik kelas VC yang berjumlah 31 orang sebagai kelas eksperimen dan peserta didik kelas VA yang berjumlah 31 orang sebagai kelas kontrol. Teknik pengambilan sampel dengan menggunakan purposive sample. Data diperoleh melalui pre-test dan post-test kemudian dianalisis menggunakan uji t-test. Data tes akhir kelas sampel dianalisis menggunakan uji-t. Hasil uji-t diperoleh $\mathrm{t}_{\text {hitung }}>$ $t_{a b e l}, 17,339>1,670$. Diperoleh $t_{\text {hitung }}$ lebih besar dari pada $t_{a b e l}$ pada taraf kesalahan $5 \%$ dan dk sebesar 5 . Berdasarkan hipotesis yang diajukan terdapat pengaruh model pembelajaran kooperatif tipe STAD terhadap hasil belajar siswa kleas V SD Negeri 1 Dompu tahun pembelajaran 2019/2020
\end{abstract}

Kata kunci: Pembelajaran, Kooperatif, STAD

\section{PENDAHULUAN}

Pendidikan nasional berfungsi mengembangkan kemampuan dan membentuk watak serta peradaban bangsa yang bermartabat dalam rangka mencerdaskan kehidupan bangsa, bertujuan untuk berkembangnya potensi peserta didik agar menjadi manusia yang beriman dan bertaqwa kepada Tuhan Yang Maha Esa, berakhlak mulia, sehat, berilmu, cakap, kreatif, mandiri, dan menjadi warga Negara yang demokratis serta bertanggung jawab. Untuk mencapai butir-butir tujuan pendidikan tersebut perlu didahului oleh proses pendidikan yang memadai. Agar proses pendidikan dapat berjalan dengan baik, maka semua aspek yang dapat mempengaruhi belajar siswa hendaknya dapat berpengaruh positif bagi diri siswa, sehingga pada akhirnya dapat meningkatkan kualitas pendidikan" (Kusumastuti, 2018: 1).

Menurut Undang-undang Nomor 20 tahun 2003 tentang Sistem Pendidikan Nasional, maka semakin kuatlah alasan pemerintah dalam melibatkan masyarakat dan pemerintah daerah dalam pengelolaan lembaga pendidikan pada jenjang pendidikan dasar dan menengah. Keterlibatan 
masyarakat dan pemerintah daerah tersebut mencakup beberapa aspek dari perencanaan, pelaksanaan, pengawasan, dan evaluasi program pendidikan (UU No. 20 Th. 2003, pasal 8), termasuk berkewajiban memberikan dukungan sumber daya dalam penyelenggaraan pendidikan. Pendidikan merupakan upaya peningkatan kualitas peserta didik setelah melalui usaha-usaha belajar guna mencapai tujuan tertentu. Tujuan yang diharapkan adalah agar peserta didik mampu mengembangkan potensi yang ada pada dirinya sehingga dapat berguna bagi diri sendiri maupun orang lain. Hal ini tercantum dalam Undang-undang Republik Indonesia Nomor 20 tahun 2003 tentang Sistem Pendidikan Nasional Pasal 1 ayat 1 yang menjelaskan bahwa: Pendidikan adalah usaha sadar dan terencana untuk mewujudkan suasana belajar dan proses belajar agar peserta didik secara aktif mengembangkan potensi dirinya untuk memiliki kekuatan spiritual keagamaan, pengendalian diri, kepribadian, kecerdasan, akhlak mulia, serta keterampilan yang diperlukan dirinya, masyarakat, bangsa dan negara. Hal tersebut dapat diwujudkan dengan sistem pendidikan yang jelas, yakni pendidikan berbasis karakter.

Pendidikan merupakan usaha sadar yang dilakukan oleh seseorang untuk mencapai kedewasaan diri. Dalam perkembangannya, istilah pendidikan atau pedagogie berarti bimbingan atau pertolongan yang diberikan dengan sengaja oleh orang dewasa agar ia menjadi dewasa Hasbullah (Cahyani, dkk: 2017: 2). Dewasa yang dimaksud adalah dapat bertanggungjawab atas dirinya sendiri atau perbuatannya sendiri. Saat ini pendidikan menjadi hal yang mendapat perhatian serius dari berbagai kalangan baik itu pemerintah, pengusaha, maupun masyarakat umum lainnya. Hal ini dikarenakan banyak orang beranggapan bahwa, dengan berpendidikan tinggi seseorang diyakini memiliki pengetahuan dan keterampilan yang bagus dan berguna bagi keberlangsungan hidup individu itu sendiri dan berguna bagi orang-orang di sekitarnya. Belajar adalah "suatu aktivitas atau suatu proses untuk memperoleh pengetahuan, meningkaatkan keterampilan, memperbaiki perilaku, sikap, dan mengokohkan kepribadian" (Suyono \& Hariyanto, 2015: 9).

Ciri-ciri perubahan tingkah laku antara lain terjadi secara sadar, bersifat kontinu, fungsional, positif, aktif, bukan bersifat sementara, bertujuan atau terarah, dan mencakup seluruh aspek tingkah laku. Siswa diharapkan dapat mengembangkan seluruh potensi yang terdapat pada dirinya dengan optimal melalui proses belajar. Cara untuk mengetahui suatu pendidikan berkualitas atau tidak dengan melihat hasil belajar siswa. Hasil belajar siswa dikatakan berhasil jika dapat mencapai tujuan pembelajaran. Hasil belajar adalah kemampuan-kemampuan yang dimiliki peserta didik setelah menerima pengalaman belajarnya. Kemampuan kemampuan tersebut mencakup aspek kognitif, afektif dan psikomotor. Hasil belajar dapat dilihat melalui kegiatan evaluasi yang bertujuan untuk mendapatkan data pembuktian yang akan menunjukkantingkat kemampuan peserta didik dalam mencapai tujuan pembelajaran.

Iskandar (Muthoharoh, 2017: 34) mengatakan bahwa hasil belajar merupakan suatu perubahan pada individu yang belajar, tidak hanya mengenai pengetahuan melainkan juga membentuk kecakapan dan penghayatan dalam diri pribadi individu yang belajar. Menurut Khodijah (Pratiwi, 2018: 2) proses pembelajaran dipengaruhi oleh beberapa komponen utama yakni pendidik, peserta didik, dan model belajar. Selain ketiga komponen di atas, hasil belajar juga dipengaruhi oleh beberapa faktor lain misalnya, minat belajar, tingkat intelegensi, fasilitas belajar, sarana dan prasarana, kurikulum, dan media belajar.

Berdasarkan hasil observasi dan wawancara yang telah dilakukan pada guru wali kelas V SD Negeri 1 Dompu, bahwa proses pembelajaran dikelas masih banyak yang menggunakan metode konvensional dan kurang kreatif dalam menyampaikan materi yaitu belum diterapkan model pembelajaran yang inovatif salah satunya model pembelajaran STAD. Sehingga hal ini dikatakan siswa cenderung mudah bosan dan kurang antusias dalam menerima materi yang disampaikan oleh pendidik dan bahkan siswa kurang terlibat secara aktif dalam kegiatan proses pembelajaran. Sehingga hal tersebut pun berdampak pada hasil pembelajarannya atau nilai rata ratanya masih 
berada di bawah standar KKM (kriteria ketuntasan minimal) sebesar 70 misalnya perolehan nilai yang didapatkan oleh siswa yakni skor 60 sedangkan nilai (KKM) siswa yaitu 70 maka otomatis nilai perolehan skor siswa tersebut belum dikatakan tuntas belum memenuhi persyaratan sesuai dengan tingkatan nilai kkm permuatan sekolah yang dimana biasanya ketercapaian daya serap tersebut ditinjau dari nilai (KKM). Sedangkan siswa yang memperoleh nilai lebih dari KKM hanya 43,35\% siswadan 56,67\% siswa yang mendapat nilai di bawah KMM. (R /17/07/2019). Walaupun sarana dan prasarana sebernanya sudah mendukung, namun kurang bervariasinya model pembelajaran yang digunakan dalam proses pembelajaran juga menyebabkan pembelajaran menjadi kurang optimal.Oleh karena itu Seorang pendidik harus kreatif dalam memilih model belajar. Model yang sesuai dengan materi, sesuai dengan tujuan pembelajaran, sesuai dengan kapasitas intelektual peserta didik, menyenangkan, dan model belajar yang harus membuat peserta didik lebih aktif dalam proses pembelajaran. Model belajar merupakan suatu unsur pola, rancangan belajar yang digunakan sebagai pedoman dalam proses belajar untuk mencapai tujuan belajar yang baik. Model belajar yang efektif adalah yang membuat peserta didik mampu berpikir kritis dan aktif dalam proses pembelajaran. Oleh karena itu perlu dilakukan suatu perubahan dalam proses pembelajaran dengan lebih fokus pada pembelajaran yang mengaktifkan siswa dengan model pembelajaran model pembelajaran kooperatif tipe Student Teams Achieviement Divisions (STAD). Shoimin (Cahyani, dkk: 2017: 4), menyatakan bahwa model pembelajaran kooperatif tipe Student Team Achievement Division (STAD) merupakan pendekatan pembelajaran kooperatif yang paling sederhana,dikatakan demikian karena kegiatan pembelajaran yang dilakukan masih dekat kaitannya dengan pembelajaran konvensional. Model ini merupakan model yang paling baik untuk permulaan bagi para guru yang baru menggunkan pendekatan kooperatif. Dalam menerapkan model pembelajaran STAD, guru memberikan sebuah topik permasalahan kepada siswa yang dipecahkan bersama melalui kegiatan diskusi kelompok dan terakhir diberikan kuis untuk membantu meningkatkan hasil belajar siswa. Pembelajaran kooperatif tipe STAD adalah salah satu tipe dari model pembelajaran kooperatif dengan menggunakan kelompok kelompok kecil dengan jumlah anggota tiap kelompok 4-5 orang siswa secara heterogen Trianto (Cahyani, dkk: 2017: 4). Berdasarkan pendapat di atas dapat di simpulkan model pembelajaran STAD adalah model pembelajaran yang membagi peserta didik menjadi beberapa kelompok yang beranggotakan 4-5 orang secara heterogen yang merupakan campuran dari peserta didik dengan kemampuan akademik, jenis kelamin, serta suku yang berbeda.

Tujuan dari penggunaan model Student Teams Achieviement Divions (STAD) adalah agar proses pembelajaran semakin bervariasi dan tidak membosankan, agar belajar peserta didik menjadi semakin aktif, dan membuat peserta didik semakin semangat dalam belajar karena mereka terlibat langsung dalam proses pembelajaran. Sesungguhnya permasalahan di atas yang menjadi inspirasi dalam penelitian ini untuk melakukan penelitian dengan judul, Pengaruh model pembelajaran kooperatif tipe STAD terhadap hasil belajar IPA siswa kelas V SD Negeri 01 Dompu tahun pembelajaran 2019/2020.

\section{METODE PENELITIAN}

Penelitian ini menggunakan pendekatan kuantitatif Jenis penelitian ini ialah eksperimen semu (Quasi Experimental Design) dengan pendekatan kuantitatif. Pendekatan kuantitatif adalah penelitian yang banyak dituntut menggunakan angka mulai dari pengumpulan data, penafsiran data, serta penampilan dari hasilnya. Jadi, cara pendekatan yang digunakan dalam penelitian ini adalah pendekatan kuantitatif yaitu suatu penelitian yang menggunakan kerangka teori, gagasan para ahli maupun pemahaman peneliti berdasarkan pengalamannya serta permasalahanpermasalahan yang diajukan untuk memperoleh pembenaran dalam bentuk dukungan data empiris. 


\section{HASIL DAN PEMBAHASAN}

\section{A. Hasil Penelitian}

Untuk mengetahui tingkat pengaruh model pembelajaran kooperatif tipe Stad dilakukan dengan pemberian tes yang diberikan kepada 31 siswa, sesuai teori yang dikemukakan oleh Arikunto (Hijriatul, 2018: 72) menyatakan bahwa "tes dilakukan untuk mengukur kemampuan dasar antara lain: tes untuk mengukur inteligensi (IQ), tes minat, tes bakat khusus, dan sebagainya". Pembagian tes akhir atau post-tes setelah diberikan perlakuan pada kelas eksperimen. Tes ini dibuat oleh peneliti dalam bentuk soal pilihan ganda sebanyak 20 item soal. Dalam kegiatan post-tes tersebut kemudian diberikan bobot nilai 5 pada masing-masing item soal, sehingga menunjukan nilai ratarata 76,04 untuk variabel (X) kelas eksperimen.

Hasil belajar diketahui dari data yang diperoleh melalui tes pilihan berganda dengan tema 6" (panas dan perpindahannya) Subtema 2" (perpindahan kalor disekitar kita) dengan materi yaitu" Menerapkan konsep perpindahan panas dalam kehidupan sehari-hari" soal tes terdiri dari 20 item yang mempunyai bobot skor 5 pada setiap item soal. Soal di berikan pada 31 siswa yang dijadikan sampel pada kelas eksperimen dan 31 sampel kelas kontrol, tes awal atau pre-test untuk mengetahui kemampuan awal hasil belajar siswa (Y) kelas kontrol dan kelas eksperimen tersebut, kemudian diberikan skor/ penilaian setiap butir soal kepada masing- masing siswa, sehingga menunjukan nilai rata-rata pre-test kelas eksperimen 50,85 dan untuk pre-test kelas kontrol yaitu 46,29 variabel (Y).

\section{B. Pembahasan}

Berdasarkan hasil penelitian hipotesis dapat diketahui bahwa ada pengaruh yang signifikan model pembelajaran Stad terhadap hasil belajar siswa SD Negeri 1 Dompu yang diajarkan menggunakan model pembelajaran Stad pada siswa. Hal ini dapat dilihat dari hasil perhitungan uji$\mathrm{t}$ yaitu $\mathrm{t}$ hitung lebih besar dari $\mathrm{t}$ tabel dengan taraf signifikan $5 \%$. Sebelum diberikan perlakuan, kedua kelas diberikan tes awal (pre-tes). Hal ini bermaksud untuk mengetahui ada atau tidaknya perbedaan kemampuan awal siswa antara kedua kelas yaitu kelas eksperimen dan kelas kontrol. dan setelah diberikanya perlakuan juga diadakan teks akhir (post-test) untuk mengetahui ada atau tidaknya peningkatan hasil belajar kedua kelas terutama kelas eksperimen yang diberikan perlakuan khusus yaitu menggunakan model pembelajaran Stad. peningkatan hasil belajar tersebut dapat dilihat dari nilai rata-rata post-tes pada kelas eksperimen dan kelas kontrol. Kedua kelas tersebut menunjukan adanya peningkatan hasil belajar. Akan tetapi, peningkatan hasil belajar yang paling menonjol ditunjukan oleh kelas eksperimen dengan nilai rata-rata post-tes 76,04 , Pada kelas kontrol menunjukan peningkatan sebesar 50,69. Selain itu juga diketahui masing-masing variabel dalam penelitian ini berdistribusi normal, hal ini dibuktikan dengan uji normalitas, kemudian dilakukan uji homogenitas dengan taraf signifikasi $5 \%$ atau a $=0,05$.

Berdasarkan hasil perhitungan selanjutnya nilai $t_{\text {hitung }}$ dibandingkan dengan nilai $\mathrm{T}_{\text {tabel }}$ dengan $\mathrm{dk}=\mathrm{n} 1+\mathrm{n} 2-2=31+31-2=60$ dan taraf signifikan 0,05 atau $5 \%$, maka $t_{\text {tabel }}=1,670$ ( uji dua pihak dengan interpolansi). Dalam hal ini berlaku ketentuan bahwa, bila $t_{\text {hitung }}$ lebih besar dari $t_{\text {tabel, }}$ maka hipotesis yang diajuakn diterima. Ternyata $t_{\text {hitung }}$ lebih besar dari pada $t_{\text {tabel }}(17,339>1,670)$ dengan taraf signifikan a $=5 \%$ maka hipotesis diterima. Simpulannya Model pembelajaran kooperatif tipe Stad berpengaruh terhadap hasil belajar siswa.

\section{SIMPULAN DAN SARAN}

\section{A. Simpulan}

Berdasarkan penelitian yang telah dilakukan tentang pengaruh model pembelajaran kooperatif tipe STAD terhadap hasil belajar siswa SD Negeri 1 Dompu Tahun Pembelajaran 2019/2020 setelah dianalisis dapat diambil kesimpulan sebagai berikut: 
1. Terdapat pengaruh hasil belajar siswa yang signifikan dengan menggunakan model pembelajaran kooperatif tipe STAD di bandingkan dengan menggunakan metode konvensional.

2. Dengan hasil uji-t diperoleh nilai thitung sebesar 17,339 dan nilai ttabel sebesar 1,670 dengan angka signifikansi 0,05 yang berarti model pembelajaran tipe STAD berpengaruh terhadap hasil belajar sehingga hipotesis diterima.

\section{B. Saran}

Berdasarkan hasil penelitian dan pembahasan dengan menggunakan model pembelajaran kooperatif tipe student teams achievement division, terdapat beberapa saran yang diperlukan pada penelitian ini sebagi berikut, diantaranya 1) Bagi guru, agar dapat Guru memahami setiap langkah model pembelajaran stad sehingga guru dapat mengajarkan kepada siswa dengan baik, Aturan yang diterapkan pada kegiatan model pembelajaran Stad harus disampaikan secara jelas dan bersifat tegas bagi seluruh siswa, Tahapan kegiatan model pembelajaran STAD dijelaskan secara rinci kepada siswa, sehingga siswa dapat mengikuti setiap tahapan dengan mudah agar bisa mengingat dengan baik. 2) Bagi siswa, Sebagai masukan bagi peserta didik terkait pelaksanaan pembelajaran dengan menggunakan model pembelajaran kooperatif tipe Student Teams Achievement Divisions, hendaknya peserta didik saling berdiskusi dan bekerja sama dengan teman kelompoknya guna memudahkan dalam memahami materi. 3) Bagi sekolah agar hendaknnya guru disekolah dapat memberikan dukungan kepada guru yang akan menerapkan model pembelajaran kooperatif tipe Student Teams Achievement Divisions, berupa fasilitas yang mendukung tercapainya proses pembelajaran secara optimal.

\section{DAFTAR RUJUKAN}

Angga Putra, \& Ija Srirahmawati. (2020). Korelasi antara Kondisi Lingkungan Keluarga Terhadap Kepatuhan Siswa Dalam Melaksanakan Tata Tertib Sekolah (Studi kasus pada siswa Sekolah Dasar). Ainara Journal (Jurnal Penelitian Dan PKM Bidang Ilmu Pendidikan), 1(2), 39-43. https://doi.org/10.1234567/ainarajournal.v1i2.12

Arifin, Fathirma'ruf, \& Ilyas Yasin. (2020). Efektivitas Belajar Al-Qur'an Dengan menggunakan Aplikasi Hijaiyah Berbasis Budaya Lokal "Nggahi Mbojo" (Bahasa Bima) Pada Lansia di Kabupaten Dompu.Ainara Journal (Jurnal Penelitian Dan PKM Bidang Ilmu Pendidikan), 1(1), 24-30. https://doi.org/10.1234567/ainarajournal.v1i1.10

Ariyanto, Metta. 2016. peningkatan hasil belajar IPA materi kenampakan rupa bumi menggunakan model SCRAMBLE, jurnal pendidikan dasar: III (2): 134- 140

Asmedy. (2020). Perbandingan Hasil Belajar Connected Mathematics Project (CMP) dengan Pembelajaran Konvensional Pada Pokok Bahasan Geometri. JIIP - Jurnal Ilmiah Ilmu Pendidikan, 3(1), 456-464. Retrieved from http://jiip.stkipyapisdompu.ac.id/jiip/index.php/JIIP/article/view/131

Astrial, As. 2018. Pemgaruh pembelajaran aktif terhadap prestasi belajar siswa di SD Negeri 29 dompu. Skripsi tidak diterbitkan. Dompu: Sekolah tinggi keguruan ilmu pendidikan(STKIP YAPIS DOMPU)

Cahyani, Mega dkk. 2017. pengaruh model pembelajaran kooperatif tipe STAD terhadap hasil belajar Pkn siswa kelas IV SD, jurnal PGSD Universitas Pendidikan Ganesha Mimbar PGSD: $\mathrm{V}(2): 1-11$

Dirman \& Juarsih cicih, (Ed). 2014. penilaian dan evaluasi.jakarta: PT rineka cipta.

Eka Yulianti, \& Taufik. (2020). Studi Perbandingan Eksistensi Alam Pada Novel Tanah Baru Tanah Air Kedua Karya Nh. Dini Dan Sri Rinjani Karya Eva Nourma (Tinjauan Ekologi 
Sastra). Ainara Journal (Jurnal Penelitian Dan PKM Bidang Ilmu Pendidikan), 1(2), 44-55. https://doi.org/10.1234567/ainarajournal.v1i2.13

Fathirma'ruf, \& Muhammad Akbar. (2018). Perancangan Sistem Seleksi Penerimaan Calon Mahasiswa Baru Berbasis Website. JIIP - Jurnal Ilmiah Ilmu Pendidikan, 1(3), 102-106. Retrieved from http://jiip.stkipyapisdompu.ac.id/jiip/index.php/JIIP/article/view/28

Fathurrohman, Muhammad. (Ed). 2107. model-model pembelajaran inovatif alternatif desain pembelajaran yang menyenangkan. jogjakarta: AR-RUZZ MEDIA.

Hijriatul. 2018. Pengaruh Penguasaan Materi Mengajar Guru Terhadap Hasil Belajar Siswa SD Negeri 29 dompu. Skripsi tidak diterbitkan. Dompu: Sekolah tinggi keguruan ilmu pendidikan(STKIP YAPIS DOMPU)

Kusumastuti, Ineke. 2018. Pengaruh model pembelajaran kooperatif tipe jigsaw terhadap hasil belajar tematik siswa kelas IV. skripsi tidak diterbitkan. Lampung. PGSD FKIP universitas Lampung.

Leni Marlina. (2020). Kajian Pengaruh Penggunaan Model Pembelajaran Picture And Picture Terhadap Prestasi Belajar IPA Siswa Sekolah Dasar. Ainara Journal (Jurnal Penelitian Dan PKM Bidang Ilmu Pendidikan), 1(2), 56-61. https://doi.org/10.1234567/ainarajournal.v1i2.14

Muthoharoh, Nurul Badriyatul. 2017. pengaruh model pembelajaran kooperatif "Think pair share (TPS)" terhadap hasil belajar bahasa inggris, jurnal SAP, (Online), Volumen 2, No. 1, (https//journal,ippmunindra.ac.id/index. php/ SAP/article/view/1509, diakses 14 juli 2019).

Neli Laa, dkk. 2017. pengaruh model pembelajaran kooperatif tipe STAD terhadap minat belajar siswa. jurnal pendidikan, (Online), jilid 2, No.2,(http://ejournal.upi,edu/index.php/jpmanper/article/view/ooooo, diakses 14 juli 2019).

Pratiwi, Clarisa. 2018. pengaruh model pembelajaran kooperatif tipe STAD terhadap hasil belajar tematik peserta didik kelas V. skripsi tidak diterbitkan. lampung: PGSD FKIP universitas bandar lampung.

Rosyidah, Ummi. 2016. pengaruh model pembelajaran kooperatif tipe jigsaw terhadap hasil belajar matematika siswa kelas VIII SMP Negeri 6 metro. jurnal SAP, Volumen I, No. 2, (https://journal.ippmunindra.ac.id/index.php/SAP/article/view/1018,diakses 15 juli 2019).

Shoimin, Aris. (Ed).2014. 68 model pembelajaran inovatif dalam kurikulum 2013. yogyakarta: ARRuzz Media

Sugiyono. 2012. metode penelitian kuantitatif kualitatif dan R\&D. Bandung: Alfabeta, CV

Sugiyono. 2014. Metode penelitian pendidikan (pendekatan kuantitatif, kualitatif dan R\&D). Bandung: Alfabeta

Suyono \& Hariyanto, (Ed). 2015. belajar dan pembelajaran. Bandung: PT remaja rosdakarya

Yasir, Muhammad \& karlina, Elin. 2015. pengaruh model penbelajaran STAD terhadap hasil belajar mata pelajaran akutansi, jurnal pendidikan: II (1): 53- 65.Asmedy. (2018). Pengembangan Perangkat Pembelajaran Bangun Datar dengan Pendekatan Open Ended. JIIP - Jurnal Ilmiah Ilmu Pendidikan, 1(2), 66-72. $\quad$ Retrieved from http://jiip.stkipyapisdompu.ac.id/jiip/index.php/IIIP/article/view/11 